\title{
National Training Center Fort Irwin Expansion Area Aquatic Resources Survey
}

C. E. Cushing

R. P. Mueller

February 1996

Prepared for the Department of Public Works,

U.S. Army, Fort Irwin, California

under a Related Services Agreement

with the U.S. Department of Energy

Contract DE-AC06-76RLO 1830

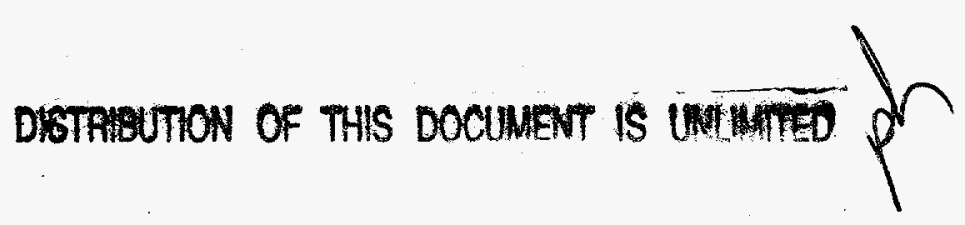

Pacific Northwest National Laboratory

Richland, Washington 99352 


\section{DISCLAIMER}

This report was prepared as an account of work sponsored by an agency of the United States Government. Neither the United States Government nor any agency thereof, nor any of their employees, makes any warranty, express or implied, or assumes any legal liability or responsibility for the accuracy, completeness, or usefulness of any information, apparatus, product, or process disclosed, or represents that its use would not infringe privately owned rights. Reference herein to any specific commercial product, process, or service by trade name, trademark, manufacturer, or otherwise does not necessarily constitute or imply its endorsement, recommendation, or favoring by the United States Government or any agency thereof. The views and opinions of authors expressed herein do not necessarily state or reflect those of the United States Government or any agency thereof. 


\section{DISCLAMIEx}

Partions of this doementent may be illegibie in electromic image produets. Images are produced from the best availabie origion doceonert 


\section{Contents}

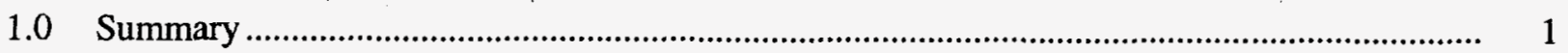

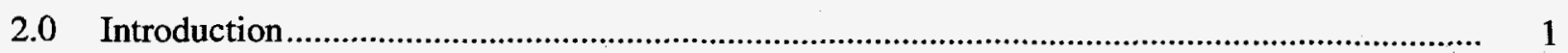

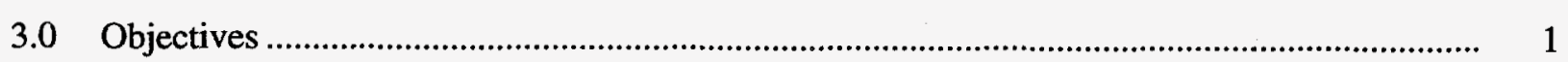

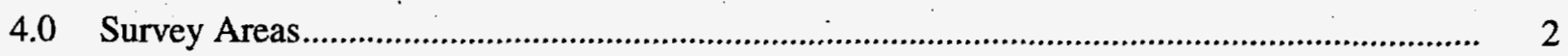

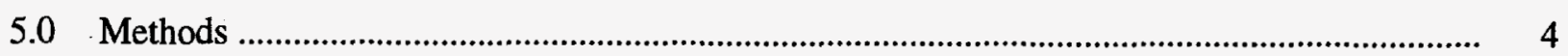

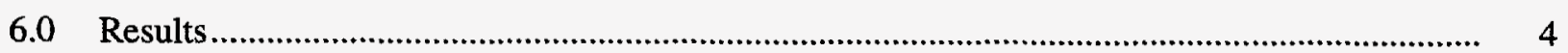

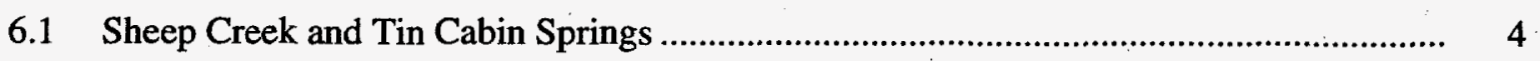

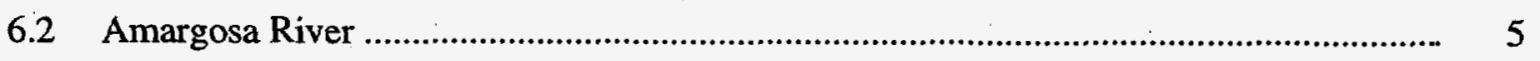

6.3 Threatened, Endangered, and Species of Concern ....................................................... 5

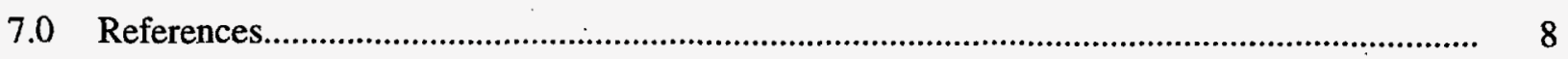

\section{Figure}

1 Map of Avawatz Mountain Area Showing Locations of Aquatic Resource Sampling Sites

\section{Tables}

1 Physical and Chemical Measurements of Sheep Creek Springs (SCS), Tin Cabin Springs (TCS), and the Amargosa River (AR), April and November 1995.

2 List of Macroinvertebrates Identified from Sheep Creek Springs (SCS), Tin Cabin Springs (TCS), and the Amargosa River (AR)... 


\subsection{Summary}

No macroinvertebrate species listed as threatened or endangered by the federal government or the State of California were found in Sheep Creek Springs (SCS) or Tin Cabin Springs (TCS) in the Avawatz Mountains, or in the Amargosa River (AR) in the vicinity of California State Highway 127. Further, no species listed by the State of California as "special animals" were identified from collections by Pacific Northwest National Laboratory (PNNL) biologists. However, the level of resolution of the taxonomic identifications does not preclude the possibility that some of the immature specimens could possibly be "special animals," although the likelihood of this is quite small given the known distributions of the California listed species. The Amargosa pupfish (Cyprinodon nevadensis) was found in the AR, but this species is not listed as a species of concern.

\subsection{Introduction}

Biologists from PNNL were requested by personnel from Fort Irwin to conduct a biological reconnaissance of the Avawatz Mountains northeast of Fort Irwin, an area for proposed expansion of the Fort. Surveys of vegetation, small mammals, birds, reptiles, amphibians, and aquatic resources were conducted during 1995 to characterize the populations and habitats present with emphasis on determining the presence of any species of special concern.

\subsection{Objectives}

The overall objectives of the ecological resource assessment of the proposed Fort Irwin expansion area were to:

- assess the abundance and distribution of species within the major habitats of the area

- assess the abundance and distribution of species within presumed sensitive habitats of the area

- characterize habitats and locales with regard to species assemblages meriting protection from disturbance.

The specific objectives of the aquatic resources survey were to:

- identify the macroinvertebrates occurring in SCS and TCS

- determine if pupfish were present in the AR in the vicinity of where it passes under California State Highway 127. 
To accomplish these goals, PNNL biologists collected samples from the springs and river in April and November of 1995 . These dates were selected to represent periods when macroinvertebrate fauna diversity was likely to be greatest - in spring prior to emergence, and in fall following egg hatching.

This report presents a description of the sites sampled, a list of the organisms found and identified, and a discussion of relative abundance. Taxonomic identifications were done to the lowest level possible commensurate with determining the status of the taxa relative to its possible listing as a threatened, endangered, or candidate species. Consultation with taxonomic experts was undertaken for the Coleoptera and Hemiptera. In addition to listing the macroinvertebrates found, we also present a discussion related to the possible presence of any threatened or endangered species or species of concern found in SCS, TCS, and the AR.

\subsection{Survey Areas}

Sampling sites are shown in Figure 1.

Sheep Creek Springs (UTM 558012E, 3938292N): SCS is a collection of small spring-seeps that eventually coalesce into a single watercourse. Some of the individual spring-seeps occur in dense grasses causing essentially pool-like conditions; others are more open and free-flowing. The main streambed averages approximately $36 \mathrm{~cm}$ wide and $5 \mathrm{~cm}$ deep. The substratum was mainly sand in the open areas with gravel and cobble where the current was rapid. In November, filamentous green algae covered the streambed where flow decreased in beds of emergent vegetation. Dense stands of tamarisk were present near the upper end of the active streambed.

Tin Cabin Springs (UTM 564802E, 3926851N): TCS originates as a significant flow within a dense stand of shrubs, flows openly for a few meters, and disappears into the coarse bed sediments. It reappears about $100 \mathrm{~m}$ below the origin in a steep-walled canyon and flows in a fairly open, gravelly bed for several hundred meters. Stream width averages about $36 \mathrm{~cm}$ and varies in depth, averaging about $8 \mathrm{~cm}$. In the lower reaches, filamentous green algae was prevalent, and the water flowed through dense growths of grasses.

Amargosa River (UTM 563705E, 3946753N): The AR at the sampling site occurs in a broad, open bed approximately $20 \mathrm{~m}$ wide. No riparian vegetation is present and the entire water surface is exposed to the sunlight. Flow is highly variable. When PNNL scientists visited the site in March prior to actual sampling, the streambed was full; however, in April, flow meandered across the bed with alternating riffles and pools, the flowing channel being about $75 \mathrm{~cm}$ wide and $12 \mathrm{~cm}$ deep. The pool areas contained soft, silty bottoms whereas the flowing portions had a gravel-cobble, highly cemented substratum. In November the river was dry. 


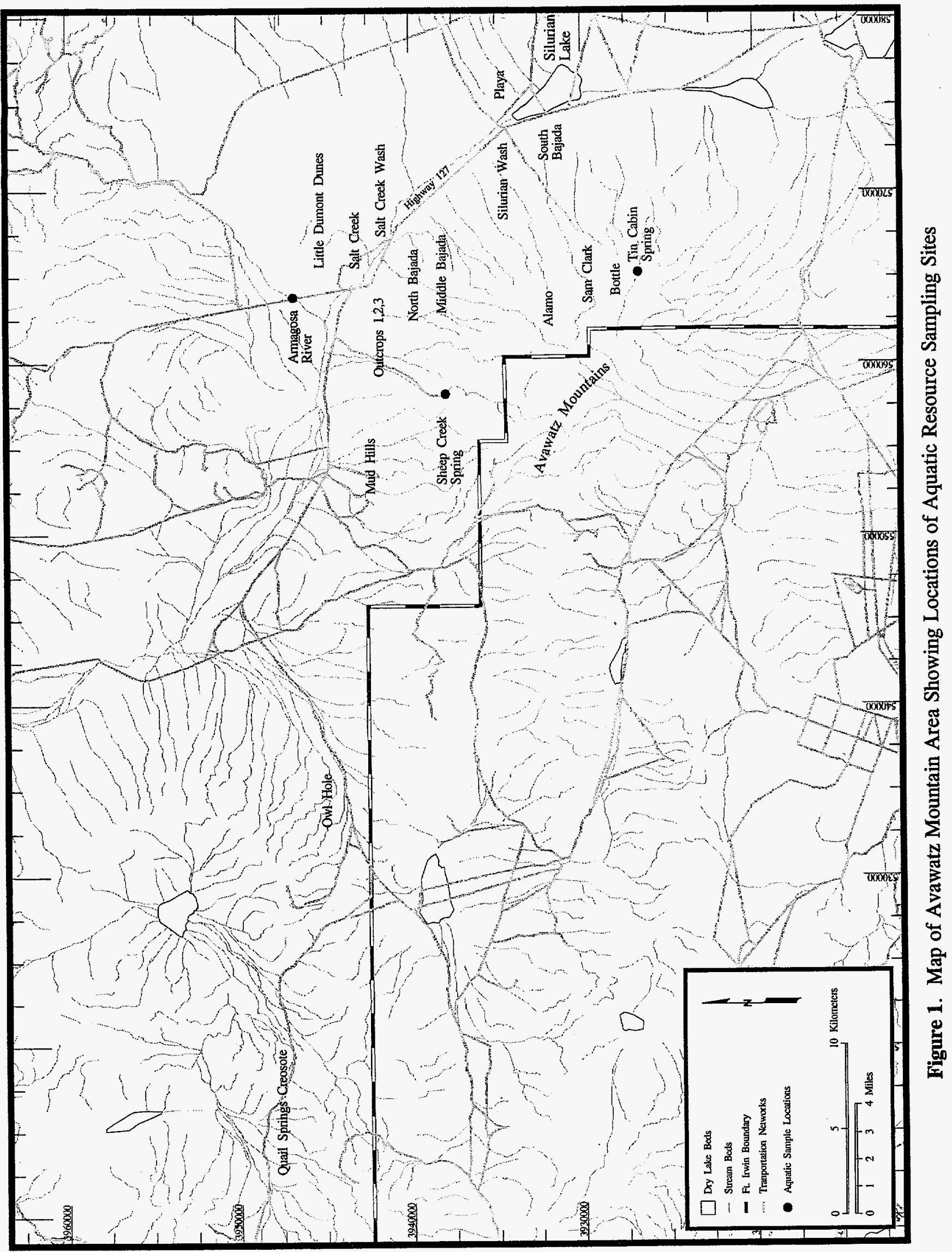




\subsection{Methods}

Physical and chemical measurements were taken in the field at each sampling site to characterize the springs and river; measurements were taken in flowing sections exposed to sunlight. Temperature and dissolved oxygen (DO) were measured with a Yellow Springs Model Y58 Dissolved Oxygen/ Temperature recorder, and $\mathrm{pH}$ and total dissolved solids (TDS) measured with hand-held analytical probes.

Macroinvertebrates were collected at the springs using various methods. A small net (mesh size $\sim 1 \mathrm{~mm}$ ) was held against the streambed perpendicular to flow while the streambed was agitated above the net and rock surfaces were brushed by hand. All material washed into the net was then transferred to a white enamel tray containing about $1 \mathrm{~cm}$ of water. Macroinvertebrates were picked from the tray with forceps. Other invertebrates were hand-picked with forceps from stones or algal mats, or picked from the stream. All organisms were placed in vials containing $70 \%$ alcohol for preservation, labeled for identification, and transported to PNNL's laboratory. Attempts were made to obtain aerial adults, but with little success.

In the AR, fish were collected with a hand dip-net. The shallowness of the water made it possible to isolate small schools of fish in pools. Macroinvertebrates were also collected from the AR on the April trip using a D-frame kick net and hand-picking from stones.

Macroinvertebrates were identified using Usinger (1956), Edmunds et al. (1976), Wiggins (1977), Pennak (1978), and Merritt and Cummins (1984). The pupfish was identified using Moyle (1976).

\subsection{Results}

\subsection{Sheep Creek and Tin Cabin Springs}

Table 1 presents the physical and chemical data for each sampling site. SCS and TCS differed considerably from the AR in all physical and chemical characteristics except DO which changed radically between April and November in the AR; temperature, TDS, and $\mathrm{pH}$ were all higher in the AR. Conditions did not change temporally in the two springs to any great extent, certainly not enough to influence the presence or absence of the taxa of macroinvertebrates found. The reason for the low DO measurements in TCS is unexplained.

Table 2 presents a list of the macroinvertebrates found at the two springs. Coleoptera, Odonata, and Ephemeroptera were the dominant organisms numerically at the two springs during both samplings trips. In November, however, a hemipteran (Veliidae:Microvelidae) was prevalent in SCS. The Ephemeroptera, mostly Baetis sp., were found in the faster flowing reaches, whereas the Coleoptera and Odonata were found in proximity to pool-like or slower flowing reaches. Chironomidae were numerous in TCS, but not found in SCS; however, it is highly likely that this widespread group of organisms is present in SCS. Many of the other taxa listed in Table 2 were represented by one or two specimens only. 
Table 1. Physical and Chemical Measurements of Sheep Creek Springs (SCS), Tin Cabin Springs (TCS), and the Amargosa River (AR), April and November 1995

\begin{tabular}{|c|c|c|c|c|c|c|}
\hline & \multicolumn{2}{|c|}{ Sheep Creek Springs } & \multicolumn{2}{|c|}{ Tin Cabin Springs } & \multicolumn{2}{|c|}{ Amargosa River } \\
\hline & Apr. & Nov. & Apr. & Nov. & Apr. & Nov. \\
\hline Temperature $\left({ }^{\circ} \mathrm{C}\right)$ & 19 & 18.7 & 16.9 & 15.8 & 29.7 & 11.9 \\
\hline $\mathrm{DO}(\mathrm{mg} / \mathrm{l})$ & 7.7 & 8.3 & 5.3 & 5.7 & 6.9 & 13.3 \\
\hline $\operatorname{TDS}(\mathrm{mg} / \mathrm{l})$ & 487 & 375 & 366 & 508 & 1290 & 1190 \\
\hline $\mathrm{pH}$ & 8.3 & 8.5 & 7.8 & 8.4 & 9.1 & 11.9 \\
\hline
\end{tabular}

\subsection{Amargosa River}

Water temperature, TDS, and $\mathrm{pH}$ were all consistently higher in the AR than in the two springs; DO was higher in November (Table 1).

In April, several schools of small fish were observed in the AR where the bridge on California State Highway 127 crosses the river. These consisted of small cyprinids and pupfish, the latter identified as the Amargosa pupfish (Cyprinodon nevadensis). In November, the river was dry at this site and flowing water was found about $6.5 \mathrm{~km}$ upstream from the bridge; numerous pupfish were found in pools here.

It was also of interest that a single specimen of hydropsychid caddisfly (Hydropsychidae: Cheumatopsyche sp.) was found at this site in April (Table 2). This is a ubiquitous family of caddisflies that is widespread in flowing waters. Yet, none were found at the spring sites and we were unable to find other specimens despite widespread sampling in the AR. Doubtless, they occur elsewhere in the AR. Ephemeroptera, Coleoptera, and Naucoridae were common. A single, empty shell of Physa sp. (Mollusca:Gastropoda) was found.

\subsection{Threatened, Endangered, and Species of Concern}

No threatened or endangered species listed by the California Fish and Game Department (California Fish and Game 1995) were found at either of the spring sites or in the Amargosa River. This was positively established, despite the fact that taxonomic identifications were not always possible to the species level, by comparison of listed species and verified identification of specimens collected.

The following discussion is intended to suggest taxa which might be worthy of concern and further emphasis on more detailed taxonomy. Reasons for this are explained.

Coleoptera: This is a notoriously difficult group of organisms to identify by the non-specialist. We sent the specimens to Dr. David White, Murray State University, a specialist in these organisms for identification. Dr. White identified two families and four (possibly five) genera (Table 2). One species of 
Table 2. List of Macroinvertebrates Identified from Sheep Creek Springs (SCS), Tin Cabin Springs (TCS), and the Amargosa River (AR); "A" denotes adult; "I" denotes larvae or immature

\section{Ephemeroptera \\ Baetidae \\ Baetis}

Trichoptera

Hydropsychidae Cheumatopsyche

Coleoptera

Dytiscidae Agabus (2 species)

Rhantus

Hydroporus

Hydrophilidae Helocombus Tropisternus Unknown 1

\section{Erpetogomphus}

Progomphus

Hemiptera

Notonectidae Notonecta

\section{Gerridae}

Gerris Trepobates

Naucoridae Ambrysus mormon

Veliidae

Microvelia

Lepidoptera

Noctuidae

Diptera

Chironomidae

Simuliidae

Ephydridae

Ephydra
A

A

A

I

I

A

A

A

A

A

A

I

A

$\mathrm{AI}^{(\mathrm{a})}$

I
A

I

A

A

A

AI

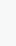

A

.

I

I

A 
Table 2. (contd)

$\underline{\text { Taxa }}$ $\operatorname{SCS}$ TCS AR

Psychodidae

Dixidae

Dixella

Tipulidae

Stratiomyidae

Ceratopogonidae

Unknown 1

Unknown 2

Oligochaeta

Mollusca

Physa (shell)

Fish

Cyprinodon nevadensis
I

I

$\mathrm{A}^{(\mathrm{a})}$

I

A A

I

A

A

A

A

A

(a) Found in small concrete pond near spring.

Agabus and three species of Hydroporus are listed as "special animals" by the California Department of Fish and Game (1994); it is not known if the specimens of these two genera found in TCS and AR are the species listed. Further taxonomical work on these genera may be warranted.

Hemiptera: We identified several specimens belonging to the genus Ambrysus sp. (Naucoridae) from the AR (Table 2). $10 \mathrm{CFR} 17$ lists Ambrysus funebris as being a candidate species, and the California Fish and Game Department (1994) lists the Amargosa naucorid bug (Pelocoris shoshone) as a "special animal." Consultation with Dr. John Polhemus, an expert in hemipteran taxonomy who is familiar with the hemipterans in this region, revealed that our specimens are A. mormon based on his description of $A$. funebris as being approximately $1-2 \mathrm{~mm}$ long; our specimens are about $1 \mathrm{~cm}$ long. Dr. Polhemus further stated that $P$. shoshone has been reclassified and has been found to be widespread throughout southern California and northern Mexico.

Diptera: Two adult and several immature dipterans were found in SCS and TCS (Table 2). California Fish and Game Department (1994) lists the dipteran Paracoenia calida, the Wilbur Springs shore fly, as being a "special animal." Darlene McGriff (California Fish and Game Department, personal communication, December 1995) states that P. calida is endemic to Wilbur Springs, located inColusa County at the northern end of the Central Valley, and thus unlikely to be found in the Avawatz Mountains area. Thus, the dipterans found in SCS and TCS are probably not included in any lists of organisms of concern.

Mollusca: Herschler (Smithsonian Institution, draft report, personal communication) reported on the springsnails (Gastropoda:Hydrobiidae) of the Mojave and Walker River Basins, and Fish Lake Valley. He found six species of Pyrgulopsis, five undescribed, and one species of Fluminicola at 11 of 97 sites he visited. Because some of these locations resulted in significant range extensions for some of the 
Pyrgulopsis species, Herschler recommended that the state consider protection for certain populations, as well as give management attention for the single known Mojave Desert population of Pyrgulopsis micrococcus (Pilsbry) and for certain populations of Fluminicola sp. We did not find any molluscs in SCS or TCS, but given the pattern of distribution shown in Herschler's draft report, it would seem likely that gastropods will be found in springs in the Fort Irwin vicinity.

\subsection{References}

California Fish and Game Department. 1994. Natural Diversity Data Base, Special Animals.

California Fish and Game Department. 1995. Endangered and Threatened Animals of California.

Edmunds, G. F., Jr., S. L. Jensen, and L. Berner. 1976. The Mayflies of North and Central America. University Minnesota Press, Minneapolis.

Merritt, R. W., and K. W. Cummins (Eds.). 1984. An Introduction to the Aquatic Insects of North America. 2nd Ed., Kendall/Hunt Publ. Co., Dubuque, Iowa.

Moyle, P. B. 1976. Inland Fishes of California. University California Press, Berkeley.

Pennak, R. W. 1978. Fresh-Water Invertebrates of the United States. 2nd Ed., John Wiley \& Sons, New York.

Usinger, R. L. 1956. Aquatic Insects of California. University California Press, Berkeley.

Wiggins, G. B. 1977. Larvae of the North American Caddisfly Genera (Trichoptera). University of Toronto Press, Toronto. 


\section{Distribution}

No. of

Copies

OFFSITE

10 M. Quillman

Department of Public Works

ATTN: ASZJ-PW-EV

Building 385

Fort Irwin, CA 92310-5097

\section{ONSITE}

\section{Pacific Northwest National Laboratory}

J. M. Becker

K6-85

C. A. Brandt

K6-85
No. of

Copies

S. L. Blanton

K6-85

D. D. Dauble

K6-85

J. A. Hall

K6-85

T. P. Hanrahan

K6-85

R. P. Mueller (20)

K6-85

D. A. Neitzel

K6-85

M. R. Sackschewsky

K6-85
Publishing Coordination

Technical Report Files (7)

Distr.1 